\title{
Global Trend of Regional Policy Greening as a Factor of Social and Economic Growth of Regions in the Russian Federation
}

\author{
Anna Popova ${ }^{1, *}$, and Marina Rudenko ${ }^{1}$ \\ ${ }^{1}$ Perm State National Research University, Department of Entrepreneurship and Economic Security, \\ 61406815 Bukireva Street 15, Perm, Russian Federation
}

\begin{abstract}
.
Research background: Sustainable development, social and economic growth not damaging the natural environment are one of the most acute problems in the modern world. The issues of the regional sustainable development in the Russian Federation as the purpose of regional policy and aspects of correlation between socio-economic development and state of regional environment were discussed in scientific papers of D.V. Novachenko, D.V. Malova, O.K. Tsapieva, L.V. Shchukina, E.A. Khrabrova, O.V. Vilchinskoy, Yu.G. Neudakhina, A.V., Okuneva, Boronnikov, D.V., E.A. Guseva, D.A., N.N. Yashalova, N.L. Yatsukova, A. Yu. Davankova, L.K., Kazantseva, T.O. Tagaeva, M.F. Zamyatina, P.V. Druzhinin, G.T. Shkiperova, O.V. Potasheva, A.A. Bashirova and others. Purpose of the article: The purpose of this article is to develop measures to improve socio-economic growth in regions on the base of theoretical and methodological substantiation of greening regional policy.

Methods: Systematic approach, methods of analysis and synthesis, logical and econometric modelling were used in this research.

Findings \& Value added: The necessity of including the environmental component in the regional policy structure was approved; the process of regional policy greening was determined; the author's methodical approach to evaluate the performance of regional policy greening was elaborated; positive changes in social and economic growth were identified with the intensification of regional policy greening; by the example of Perm Krai measures to promote the regional policy greening performance were developed.
\end{abstract}

Keywords: sustainable development; regional environment; regional policy; social and economic growth

JEL Classification: $C 510 ; Q 58 ; R 11$

\footnotetext{
* Corresponding author: voronina-hub@yandex.ru
} 


\section{Introduction}

Sustainable development, social and economic growth not damaging natural environment are one of the most acute problems in modern world. The problem of the relationship between economic and social development and the state of the environment is widely covered in the international scientific literature [1-10]. The issues of the regional sustainable development in the Russian Federation as the purpose of regional policy and aspects of correlation between socio-economic development and state of regional environment were discussed in scientific papers of D.V. Novachenko, D.V. Malova [11], O.K. Tsapieva [12], L.V. Shchukina [13], O.V. Vilchinskaya, E.A. Khrabrova, E.A. Guseva [14], Yu. G. Neudakhina [15], A.V., Okuneva, D.A. Boronnikov [16], N.N. Yashalova [17], A. Yu. Davankov, N.L. Yatsukova [18], L.K., Kazantseva, T.O. Tagaeva [19], M.F. Zamyatina [20], P.V. Druzhinin, G.T. Shkiperova, O.V. Potasheva [21], A.A. Bashirova [22] and others.

Nevertheless, the current regional policy in Russia gives the priorities to only socioeconomic development. The analysis of 63 Russian regional strategies reveals that $12 \%$ of strategies miss the importance of environmental development and around $70 \%$ of them lck any environmental indicators [23]. Thereby, it is nessesary to aprove the content of regional policy as a complex of measures for the socio-economic and environmental growth of regions. The purpose of this research is to develop measures to improve socio-economic growth in regions on the base of theoretical and methodological substantiation of greening regional policy.

\section{Methodology}

The theoretical and methodological base of this study consisted of modern regional policy and sustainable development researches. Systematic approach, methods of analysis and synthesis, logical and econometric modelling were used in this research. The evaluationg of the performance of regional policy greening was carried out for the regions of the Volga Federal District (hereinafter - VFD): Nizhny Novgorod Region, Orenburg Region, Perm Krai, Republic of Bashkortostan, Republic of Tatarstan, Samara Region. All calculations were based on data for 2010-2015.

\section{Results and Discussion}

The researh aproved the nessesity to supplement the content of regional policy with an allsufficient environmental component including aim, tasks, measures and instruments. Further, each regional polisy component should be additionally oriented on improving environmental processes:

1) an economic componen, increasing gross regional product (hereinafter - GRP) while preserving environment and social capital;

2) a social component, increasing the life level and quality and enabling favorable environment;

3) an environmental component, aiming on iproving the self-healing abilities of the natural systems.

The environmental component being part of the regional policy affects the social and economic regional growth in several directions. Thus, it is possible to clarify the content of the "regional policy greening" process:

1) adding environmental objectives to the regional policy priorities;

2) implementation of the economic policy based on environmental constraints on the anthropogenic load on the environment, high-tech and environmentally friendly productions in the GRP structure, greening the investments structure; 
3) amplification of the regional social policy on the base of improving living conditions.

Specific regional features, including natural and climatic conditions, economic characteristics and regions' specialization, allocation of industrial productions and residets resettlement, sociocultural features, etc. define:

1) the maximum possible socio-economic effect of the potential environmental positive impact ("benchmark" parameters);

2) and the minimum allowable impact level, below which destructive changes in social and economic growth are possible ("threshold" parameters).

Evaluation of regional policy performance in Russian economic literature does not usually take into account the environmental component [24, 25]. Difficulties and sometimes impossibility of evaluating regional policy effectiveness with regard to its environmental component are caused by failure of measures and target indicators oriented on the solution of environmental problems in regional development programs. Significance of assesing the greening regional policy (as the unity of the three components) performance determines the necessity to focus on the performance as a compliance degree of factual environmental and socio-economic indicators with "benchmark" indicators. In this connection, autors' methodology for evaluating regional policy performance was introduced (hereinafter evaluationg of the performance of regional policy greening). The presented methodology takes into account the environmental component of the regional policy and its impact on the social and economic development. It also considers specifics of the environmental development evaluation. The sequance of carring out the evaluayion is described below.

Step 1. Selection of regions for evaluation in conformity with the criteria: 1) consimilar climatic conditions, which determines relatively similar "benchmark" and "threshold" parameters of the regional policy greening performance (region of one federal district); 2) high level of economic development (GRP per capita is above the average in the federal district); 3) consimilar economic specialization (the share of mining and processing industries in the structure of GRP is not less then $30 \%$ ).

Step 2. Determination of evaluation indicators. In this research only one natural sphere was used to test the methodology: atmospheric air. Nevertheless, methodology concept makes it possible to include into the research any number of natural spehers. The following units of indicators were formed:

Table 1. Units of indicators for evaluating regional policy greening performance.

\begin{tabular}{|c|c|c|}
\hline $\begin{array}{c}\text { Unit A: environmental } \\
\text { development indicators }\end{array}$ & $\begin{array}{c}\text { Unit B: economic } \\
\text { development greening } \\
\text { indicators }\end{array}$ & $\begin{array}{c}\text { Unit C: social } \\
\text { development greening } \\
\text { indicators }\end{array}$ \\
\hline $\begin{array}{c}\text { Investments in fixed } \\
\text { assets for the } \\
\text { atmospheric air } \\
\text { protection (\% of GRP) }\end{array}$ & $\begin{array}{c}\text { High-tech industries in } \\
\text { the GRP structure (\%) }\end{array}$ & $\begin{array}{c}\text { Disease incidence rates of } \\
\text { the population due to the } \\
\text { air pollution: respiratory } \\
\text { disease (cases per 1000 } \\
\text { population) }\end{array}$ \\
\hline $\begin{array}{c}\text { Pollutant air emissions } \\
\text { productivity (bln. rub. of } \\
\text { GRP per thous. tons of } \\
\text { emissions) }\end{array}$ & $\begin{array}{c}\text { Main polluting industries } \\
\text { in the GRP structure (\%) }\end{array}$ & $\begin{array}{c}\text { Disease incidence rates of } \\
\text { the population due to the } \\
\text { air pollution: cancer (cases } \\
\text { per 1000 population) }\end{array}$ \\
\hline $\begin{array}{c}\text { Share of the population } \\
\text { living in low air } \\
\text { pollution cities (\%) }\end{array}$ & Depreciation of fixed & $\begin{array}{c}\text { Disease incidence rates of } \\
\text { the population due to the } \\
\text { air pollution) anomalies } \\
\text { and malformations (cases } \\
\text { per 1000 population) }\end{array}$ \\
\hline
\end{tabular}


Step 3. Relative indicators $\left(\mathrm{KPI}_{\mathrm{i}}\right)$ calculation. $\mathrm{KPI}_{\mathrm{i}}=100 \%$ corresponds to the "benchmark" parameter, $\mathrm{KPI}_{\mathrm{i}}=0 \%$ corresponds to "threshold" parameter. Thus, indicators of $\mathrm{A}, \mathrm{B}, \mathrm{C}$ units were normalized using $\mathrm{KPI}_{\mathrm{i}-\mathrm{S} \text { : }}$

$$
K P I_{i}=\frac{\left|X_{\text {fact }}-X_{\text {thr }}\right|}{\left|X_{\text {bench }}-X_{\text {thr }}\right|} * 100 \%
$$

where $\mathrm{KPI}_{i}-\mathrm{KPI}$ index of the $i$-th evaluating indicator in the reporting period; $\mathrm{X}_{\text {fact }}$ -

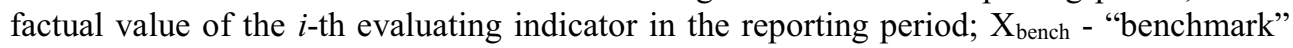
parameter of the $i$-th evaluating indicator (in this research the best value for the evaluating regions in the reporting period was used); $\mathrm{X}_{\text {thr }}$ - "threshold" value of the $i$-th evaluating indicator (in this research the worst value for the evaluating regions in the reporting period was used).

Step 4. Relative indicators for each regional policy components $\left(\mathrm{KPI}_{\text {jcomp }}\right)$ and integral indicator of the regional policy greening performance (KPIregpol) calculation:

$$
K P I_{j \text { comp }}=\sum_{i=1}^{n} w_{i} * K P I_{i}
$$

where $\mathrm{KPI}_{\text {comp }}$ - KPI index for the $j$-th regional policy component in the reporting period; $\mathrm{KPI}_{i}$ - KPI index of the $i$-th evaluating indicator in the reporting period; $\mathrm{w}_{i}$ - weight of the $\mathrm{KPI}_{i}$ in the $\mathrm{KPI}_{j}\left(0<\mathrm{w}_{i}<1 ; \sum \mathrm{w}_{i}=1\right.$; the weights of $\mathrm{KPI}_{i}$ indexes in the $\mathrm{KPI}_{j c o m p}$ index were taken equal).

$$
K P I_{\text {reg pol }}=\sum_{j=1}^{n} w_{j} * K P I_{j \text { comp }}
$$

where $\mathrm{KPI}_{\text {regpol }}$ - is the integral KPI index of the regional policy greening performance in the reporting period; $\mathrm{KPI}_{\text {jcomp }}$ - KPI index for the $j$-th regional policy component in the reporting period; wj - weight of the $\mathrm{KPI}_{\text {jcomp }}$ index in the integral KPI index of the regional policy greening performance $\left(0<\mathrm{w}_{j}<1 ; \sum \_\mathrm{w}_{j}=1\right.$; the weights of $\mathrm{KPI}_{\text {jcomp }}$ indexes were taken equal).

The closer the KPI $\mathrm{I}_{\text {regpol }}$ value is to "100\%", the higher the level of regional policy greening performance.

Step 5. Region classification and ranking by the level of regional policy greening performance:

Table 2. Units of indicators for evaluating regional policy greening performance.

\begin{tabular}{|c|c|c|}
\hline $\begin{array}{c}\text { Group I: Low regional } \\
\text { policy greening } \\
\text { performance }\end{array}$ & $\begin{array}{c}\text { Group II: Medium } \\
\text { regional policy greening } \\
\text { performance }\end{array}$ & $\begin{array}{c}\text { Group III: High regional } \\
\text { policy greening } \\
\text { performance }\end{array}$ \\
\hline $\mathrm{KPI}_{\text {regpol }}=[0 ; 33 \%]$ & $\mathrm{KPI}_{\text {regpol }}=[34 ; 66 \%]$ & $\mathrm{KPI}_{\text {regpol }}=[67 ; 100 \%]$ \\
\hline
\end{tabular}

Step 6. Calculation of the unevenness degree of regional policy greening performance:

$$
\sigma_{K P I_{n}}=\sqrt{\frac{1}{l} \sum_{m=1}^{l}\left(K P I_{n_{m}}-\overline{K P I}_{n}\right)^{2}}
$$

where $\sigma_{\mathrm{KPI} n}$ - unevenness degree of the $n$-th KPI index ( $n$-th KPI index may be: 1$) i$-th evaluatingt indicator $\left.\left(\mathrm{KPI}_{i}\right), 2\right) \mathrm{KPI}$ index for the $j$-th of regional policy component $\left(\mathrm{KPI}_{\text {jcomp }}\right)$, 3 ) the integral KPI index of the regional policy greening performance (KPI regpol)); $\mathrm{KPI}_{n m}-n$ th KPI index for the $m$-th region; $\overline{\mathrm{KPI}}_{n}$ - arithmetic average value of the $\mathrm{n}$-th KPI index for the evaluating regions in the reporting period.

Step 7. Decomposition of indicators for evaluating environmental component performance (industry and municipal levels).

Step 8. Forecasting of social, economic and environmental indicators in two scenarios 1) maintaining current trends 2) amplification of regional policy greening.

Results of the regional policy greening performance evaluation are represented in the Tables 3-5. 
Table 3. Regional policy greening performance (KPI $\mathrm{Ieg} \mathrm{pol}_{\text {) }}$ of VFD regions, \%, 2010-2015.

\begin{tabular}{|c|c|c|c|c|c|c|c|}
\hline Region & $\mathbf{2 0 1 0}$ & $\mathbf{2 0 1 1}$ & $\mathbf{2 0 1 2}$ & $\mathbf{2 0 1 3}$ & $\mathbf{2 0 1 4}$ & $\mathbf{2 0 1 5}$ & $\begin{array}{c}\text { Performance } \\
\text { in 2015 }\end{array}$ \\
\hline $\begin{array}{c}\text { Rep. of } \\
\text { Tatarstan }\end{array}$ & 76.0 & 65.7 & 70.7 & 61.1 & 69.5 & 80.4 & high \\
\hline $\begin{array}{c}\text { Rep. of } \\
\text { Bashkort } \\
\text { ostan }\end{array}$ & 50.1 & 64.0 & 62.0 & 75.0 & 57.3 & 68.5 & high \\
\hline $\begin{array}{c}\text { Nizhny } \\
\text { Novgoro } \\
\text { d Region }\end{array}$ & 59.3 & 58.7 & 55.5 & 53.8 & 55.3 & 67.3 & high \\
\hline $\begin{array}{c}\text { Orenburg } \\
\text { Region }\end{array}$ & 35.7 & 37.8 & 35.2 & $39, .0$ & 35.3 & 47.9 & medium \\
\hline $\begin{array}{c}\text { Samara } \\
\text { Region }\end{array}$ & 33.7 & 34.4 & 34.9 & 33.2 & 40.9 & 31.2 & low \\
\hline $\begin{array}{c}\text { Perm } \\
\text { Krai }\end{array}$ & 23.0 & 32.4 & 33.1 & 33.2 & 24.8 & 26.6 & low \\
\hline
\end{tabular}

The growth of regional policy greenenig performance in almost all the evaluating regions is obvious. This could be explained by the amplification of environmental development processes and strengthening of its impact on the regional socio-economic development. However, there are still reserves for the growth of regional policy greening performance remaining, as the "benchmark" parameters are not achieved. The worst values are shown by such economic indicators as are: depreciation of fixed assets and share of main polluting industries in the GRP structure (especially in Orenburg Region and Perm Krai); The worst values of social indicators are shown by the incidence of diseases of the respiratory organs, the presence of anomalies and malformations (especially in Nizhny Novgorod Region, Perm Krai, Samara Region,).

Results of calculation of the unevenness degree of regional policy greening performance are shown in Table 4.

Table 4. Unevenness degree of the performance indicators $\left(\sigma_{K P I_{n}}\right)$ for VFD regions, \%, 2010-2015.

\begin{tabular}{|l|c|c|c|c|c|c|c|}
\hline $\begin{array}{l}\text { Unevenness degree } \\
\text { of the performance } \\
\text { indicators }\left(\boldsymbol{\sigma}_{\boldsymbol{K} \boldsymbol{P}_{\boldsymbol{n}}}\right)\end{array}$ & $\mathbf{2 0 1 0}$ & $\mathbf{2 0 1 1}$ & $\mathbf{2 0 1 2}$ & $\mathbf{2 0 1 3}$ & $\mathbf{2 0 1 4}$ & $\mathbf{2 0 1 5}$ & $\Delta \boldsymbol{\sigma}_{\boldsymbol{K P I}_{\boldsymbol{n}}}$ \\
\hline $\begin{array}{l}\text { Regional policy } \\
\text { greening, including: }\end{array}$ & 5.1 & 5.5 & 3.8 & 5.6 & 5.3 & 7.8 & $\uparrow$ \\
\hline $\begin{array}{l}\text { economic } \\
\text { development } \\
\text { greening }\end{array}$ & 12.8 & 10.2 & 10.4 & 10.3 & 10.9 & 10.5 & $\downarrow$ \\
\hline $\begin{array}{l}\text { social development } \\
\text { greening }\end{array}$ & 7.6 & 10.5 & 6.1 & 12.0 & 9.3 & 9.3 & $\uparrow$ \\
\hline $\begin{array}{l}\text { environmental } \\
\text { component, } \\
\text { including: }\end{array}$ & 2.9 & 4.3 & 4.4 & 6.8 & 6.5 & 11.1 & $\uparrow$ \\
\hline $\begin{array}{l}\text { investments in fixed } \\
\text { assets for the } \\
\text { atmospheric air } \\
\text { protection }\end{array}$ & 12.9 & 13.9 & 13.4 & 14.8 & 14.5 & 17.0 & $\uparrow$ \\
\hline
\end{tabular}




\begin{tabular}{|l|c|c|c|c|c|c|c|}
\hline $\begin{array}{l}\text { pollutant air } \\
\text { emissions } \\
\text { productivity }\end{array}$ & 14.0 & 13.8 & 13.4 & 13.7 & 13.6 & 13.5 & $\downarrow$ \\
\hline $\begin{array}{l}\text { share of the } \\
\text { population living in } \\
\text { low air pollution } \\
\text { cities }\end{array}$ & 13.1 & 13.3 & 13.1 & 13.1 & 14.3 & 16.0 & $\uparrow$ \\
\hline
\end{tabular}

Relaying on data presented in the Table 4 an increase in the gap in the levels of regional policy greening performance among regions was revealed. The gap is caused by the increase in the unevenness of the volume of investments in fixed assets for the atmospheric air protection and levels of air pollution in cities. Positive changes in solving air quality problems and greening the equipment used in main industries are obvious in the Republics of Bashkortostan and Tatarstan, Nizhny Novgorod and Orenburg regions. At the same time, lack of regional policy greening is presented in regions of Perm Krai and Samara Region. Revealed shifts indirectly affect the growth of the social development greening uneveness (increasing gaps in the values of morbidity indicators).

By an example of Perm Krai, which had taken the last pplace in the rating of regional policy greening performance (Table 3), the values of environmental development indicators were decomposed on industry and municipal levels. As a result, the limitations of greening processes were revealed: environmentally unfriendly development of the transport and communications industry, industry of production and distribution of electricity, gas and water and mining industry. The major limitative factors of these productions are: depreciation of fixed assets and outdated technologies (especially, associated petroleum gas (hereinafter APG) flaring). As the most problematic cities were identified: Perm, Berezniki, Solikamsk, Krasnokamsk and Lysva. The major limitative factors of these territories are high concentration of industrial enterprises (especially, chemical and petrochemical businneses, metallurgy and power generation production) and growth of air pollutant emissions from road transport.

Using the example of Perm Krai forecasting of social, economic and environmental indicators was carried out in two scenarios 1) maintaining current trends 2) amplification of regional policy greening. In each econometric model describing one of the evaluating indicators one of the explanatory factors was changed while maintaining the fixed values of the others: for the first scenario the value of the environmental indicator was changed in accordance with the identified 2010-2015 trend; for the second scenario the value of the environmental indicator was improved in accordance with the best shown regional performance. The values of the best performance results were obtained by analysis of evaluating VDF regions indicators for the period 2010-2015.

Relying on forecast data it can be concluded that:

1) growth of the proportion of the population living in low air pollution cities by $5 \%$ per year provides an annual decline in the incidence of respiratory diseases by 25.8 cases per 1000 population on average;

2) growth of investments in fixed assets for the atmospheric air protection by $0.01 \%$ of GRP per year provides an annual decline in the growth rate of the incidence of respiratory diseases in the population by of 0.28 on average $\%$.

3 ) use of environmentally friendly equipment and technologies meaning the decline of depreciation of fixed assets by $5 \%$ per year provides an annual growth of pollutant air emissions productivity by 1.42 billion rubles. GRP per thous. tons of emissions on average.

Thereby, positive changes in social and economic growth are becoming more rapid with the intensification of regional policy greening. 
Table 5. Fragment of the socio-economic and environmental indicators forecast for Perm Krai, 20182020: incidence of respiratory diseases

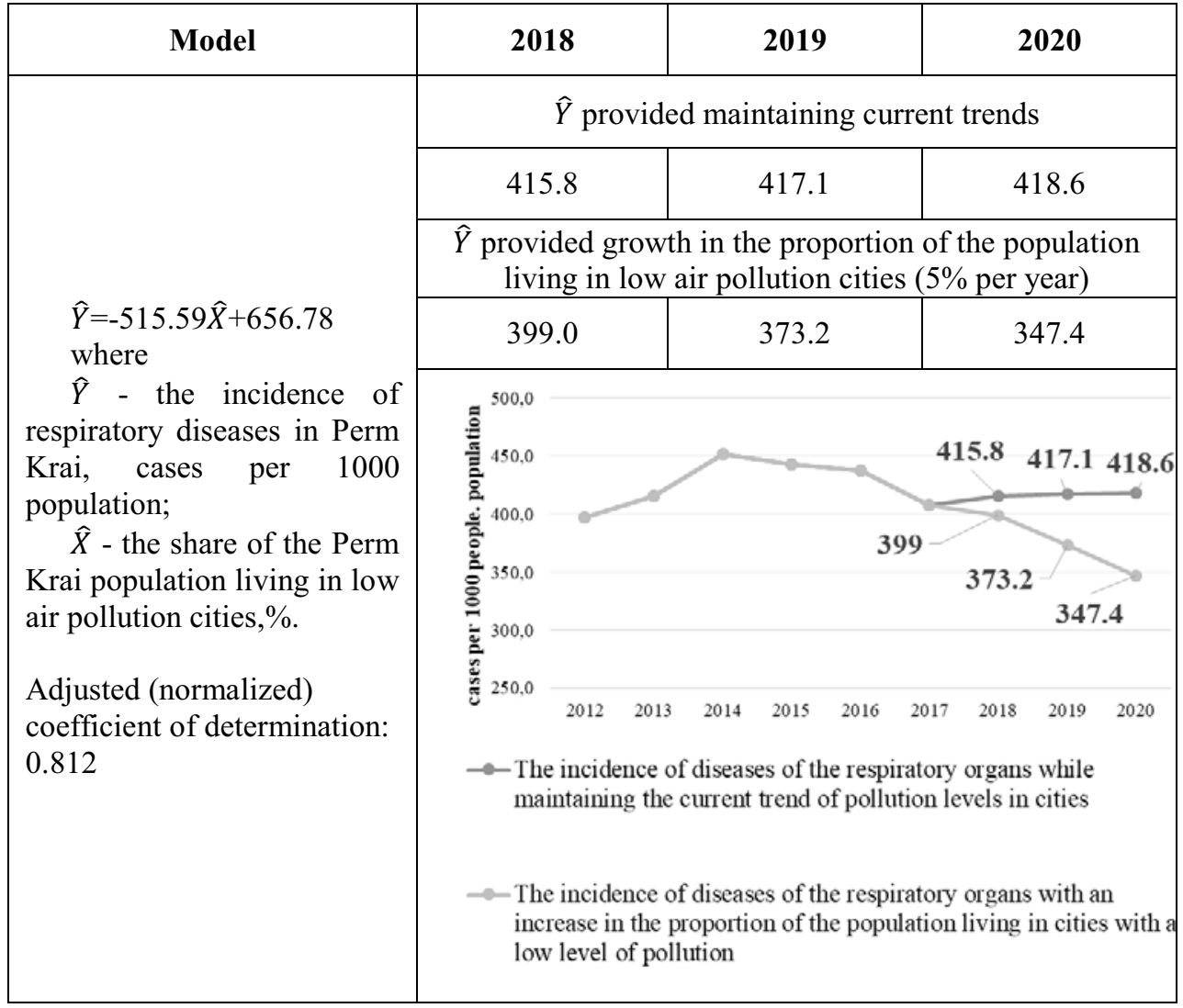

Analysis of the regional policy greening processes was conducting. According to it, tools of an environmental development in VDF regions were systematized as: 1) "environmental" tax benefits; 2) inclusion of environmental goals and objectives into regional development strategies and specialized programs; 3) institutional tools, including development of public institutions that provide greening processes publicity. The analysis also revealed a lack of application of transport tax benefits in regional management practice as well as insufficient elaboration of specialized programs on atmospheric air protection and the creation of favorable living environment. Particullaly, during the period of 2006-2012 in Perm Krai there was no specialised program on environmental development. The current program for the environment protection does not include measures to reduce air pollutant emissions and stimulating greener production law instruments.

Based on the analysis major directions for improving regional policy greening performance in Perm Krai were introduced:

1) To establish "environmental" profit tax benefits for businesses, which modernize production, introduce environmentally friendly technologies, reduce the share of flaring APG, etc: establish "environmental" transportation tax benefits for owners of high ecological class vehicles.

2) To introduce a mechanism of investment tax credits for projects of equipment and technologies environmental modernization.

3) To amend the current regional program on environmental protection, including goals, target indicators and list of investment projects oriented on air protection. 
4) To establish a specialised program on cities infrastructure modernisation: transfer industrial productions from the populated areas to special industrial parks; design sanitary protection zones of enterprises (hereinafter - SPZ); resettle the population living in the SPZs; "green" the landscape of settlements; rationalize cities transport infrastructure.

5) To introduce a mechanism of regular regional policy greening performance evaluation.

To summarize the study, it can be concluded that the necessity of including the environmental component in the regional policy structure was approved; the process of regional policy greening was determined; the author's methodical approach to evaluate the performance of regional policy greening was elaborated; positive changes in social and economic growth were identified with the intensification of regional policy greening; by the example of Perm Krai measures to promote the regional policy greening performance were developed.

\section{References}

1. Sun, Y., Ding, W., Yang, Z. (2020). Measuring China's regional inclusive green growth. Science of the total environment, 713, 136367.

2. Liu, H., Huang, B., Yang, C. (2020). Assessing the coordination between economic growth and urban climate change in China from 2000 to 2015. Science of the total environment, $732,139283$.

3. Udemba, E.N. (2020). A sustainable study of economic growth and development amidst ecological footprint: New insight from Nigerian Perspective. Science of the total environment, 732, 139270.

4. Baz, K., Xu, D., Ali, H. (2020). Asymmetric impact of energy consumption and economic growth on ecological footprint: Using asymmetric and nonlinear approach. Science of the total environment, 718, 137364.

5. Adedoyin, F.F., Alola, A.A., Bekun, F.V. (2020). An assessment of environmental sustainability corridor: The role of economic expansion and research and development in EU countries. Science of the total environment, 713, 136726.

6. Chen, Y., Liu, A.; Cheng, X. (2020). Quantifying economic impacts of climate change under nine future emission scenarios within CMIP6. Science of the total environment, 703, 134950.

7. Joshua, U.; Bekun, F.V.; Sarkodie, S.A. (2020). New insight into the causal linkage between economic expansion, FDI, coal consumption, pollutant emissions and urbanization in South Africa. Environmental science and pollution research, 27(15 SI), 18013-18024.

8. Cao, Y., Wan, N., Zhang, H. (2020). Linking environmental regulation and economic growth through technological innovation and resource consumption: Analysis of spatial interaction patterns of urban agglomerations. Ecological indicators, 112, 106062.

9. Udemba, Edmund Ntom; Magazzino, Cosimo; Bekun, Festus Victor. (2020). Modeling the nexus between pollutant emission, energy consumption, foreign direct investment, and economic growth: new insights from China. Environmental science and pollution research, 27(15 SI), 17831-17842.

10. Wang, J., Wei, X., Guo, Q. (2018). A three-dimensional evaluation model for regional carrying capacity of ecological environment to social economic development: Model development and a case study in China. Ecological indicators, 89, 348-355.

11. Tsapieva, O. K. (2010). Sustainable development of a region: theoretical foundations and the model. Problems of modern economy, 2(34), 12-27.. 
12. Shchukin, L.V. (2015). Theoretical aspects of sustainable development of regional social - economic systems. Pskov Regional Journal, 21, 38 - 50.

13. Vil'chinskaya, O. V., Khrabrov, E. A., \& Gusev, E. A. (2011). Sustainable and complex social-economic development: state, region, municipal entities. Terra Economicus, 9(13), 114-119.

14. Neudahina, Yu.G. (2011). Sustainable development as a strategic goal of regional policy, Management of economic systems: electronic scientific journal, 3(27), 35-39.

15. Okuneva, A.V., Boronnikov, D.A. (2013). Planning of the regional policy of the Russian Federation taking into account the concept of sustainable development. News of Moscow State Technical University MAMI, V1, 4(18), 292-295.

16. Novachenko, D.V., Malov, D.V. (2013). Sustainable development of the region. Bulletin of the Russian Economic University named after G.V. Plekhanov, 4, 34-41.

17. Yashalova, N.N. (2014). Analysis of the decoupling effect in the region's environmental - economic activities. Regional Economics: Theory and Practice, 39(366), 54-61.

18. Davankov, A.Yu., Yatsukova, N.L. (2015). Three-factor model for assessing the balance of development of regional subsystems. Bulletin of Chelyabinsk State University, 18(373), 28-38.

19. Zamyatin, M.F. (2016). Greening industrial policy as a factor of regional development. Business Strategies, 4(24), 6-9.

20. Kazantseva, L.K., Tagaeva, T.O. (2014). The impact of environmental pollution on the health of the population in the regions of the Urals, Siberia and the Far East. Interexpo GEO, Siberia, X Intern. scientific cong. and exhibition, "The economic development of Siberia and the Far East. Economics of environmental management, land management, forest management, real estate management": Comp. of materials in 2 vol. (pp. 175180), Sib. state geodesic Acad., Novosibirsk.

21. Bashirova, A.A. (2016). Determining the decoupling effect for problem areas in modern conditions (on the example of the regions of the North Caucasus Federal District). Management of Economic Systems: electronic scientific journal, 10(92), 4.

22. Druzhinin, P.V., Shkiperova, G.T., Potasheva, O.V. (2018). Assessment of the impact of economic development on the state of the environment and greenhouse gas emissions. Drucker Bulletin, 2(22), 203-215.

23. Ilinbaeva, E.A. (2016) Assessment of the effectiveness of the development strategies of the regions of the federation based on the consideration of the environmental component: author. dis. ... PhD: 08.00.05.Ekaterinburg.

24. Ostroumov, A.I., Ostroumova, O.F. (2015). Regional policy in modern Russia: state and development trends. Historical, philosophical, political and legal sciences, cultural studies and art history. Theory and practice, 12(62), 119-123.

25. Sidorenko, O.V. (2017). Methodological tools for assessing the effectiveness of the regional policy of the Russian Federation. Bulletin of the Khabarovsk State University of Economics and Law, 2(88), 71-75. 